\title{
ANALISA KESESUAIAN LAHAN TEH DI BANJARNEGARA MENGGUNAKAN TEKNOLOGI PENGINDERAAN JAUH DAN SISTEM INFORMASI GEOGRAFIS
}

\section{Land Suitable Analysis of Tea Area in Banjarnegara Using Remote Sensing and Geographic Information System}

\author{
Abdi Sukmono \\ Program Studi Teknik Geodesi, Fakultas Teknik Universitas Diponegoro \\ Email : sukmono35@gmail.com
}

\begin{abstract}
Abstrak
Teh merupakan komoditas unggulan Kabupaten Banjarnegara. Peluang pengembangan teh di banjarnegara sangat baik karena pasar ekspor yang masih belum terpenuhi. Akan tetapi masih minimnya informasi terkait daerah yang sesuai untuk budidaya teh menyebabkan investasi the di Banjarnegara tidak berkembang dengan pesat. Penelitian ini menggunakan teknologi penginderaan jauh dan Sistem informasi Geografis untuk menganalisa daerah potensi pengembangan budidaya teh berdasarkan kesesuaian lahan. Hasil dari penelitian ini menunjukkan lahan yang sesuai (S2) untuk budidaya teh seluas $2147,21 \mathrm{Ha}(6,58 \%)$ dan Sesuai marjinal (S3) seluas 6882,32 Ha (21,10\%). Validasi hasil peta ini dilakukan dengan ground truth pada 32 titik sampel dengan tingkat kebenaran $88 \%$.
\end{abstract}

Kata Kunci: Teh, Kesesuaian lahan, Penginderaan Jauh, SIG

\begin{abstract}
Tea is a priority commodities in Banjarnegara. The opportunities of cultivation of tea in Banjarnegara is very good because there are many market eksport. However, information of land suitable area for tea cultivation is still a little. This research using remote sensing technology and Geographic Information Systems to analyze the potential area for the development of tea cultivation based on land suitability. The results of this study indicate moderately suitable ( S2

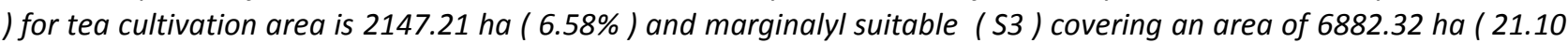
$\%)$. Validation of the results of this map used ground check at 32 sample points with $88 \%$ degree of truth.
\end{abstract}

Keywords: Tea, Land suitability, Remote sensing, GIS

\section{PENDAHULUAN}

\section{Latar Belakang}

Teh merupakan salah satu komoditas unggulan Indonesia. Sebagian besar (70\%) teh Indonesia diekspor sehingga Indonesia tercatat menjadi urutan keenam eksportir teh dunia setelah Kenya, Sri Lanka, India dan Vietnam. Negara tujuan ekspor teh Indonesia adalah Jepang, Korea Selatan, Amerika Serikat dan negaranegara Eropa. Berdasarkan data Dewan Teh Indonesia (2013), tercatat konsumsi teh dunia terus naik dari tahun ke tahun, hal ini menjadi potensi pasar tersendiri bagi perkembangan teh Indonesia.

Salah satu penghasil teh di Indonesia adalah Kab. Banjarnegara. Teh menjadi salah satu komoditas unggulan Kabupaten Banjarnegara, hal ini ditunjang dengan kondisi iklim dan keadaan alam Banjarnegara yang sangat potensial untuk pengembangan budidaya teh. Luas Perkebunan Teh di Kabupaten Banjarnegara 2.334,64 Ha dengan jumlah produksi secara keseluruhan sebesar 1.993 Ton / tahun. produktivitas tanaman teh di Banjarnegara belum mampu memenuhi permintaan sejumlah pabrik teh di luar kota. Dari permintaan 32 ton per hari hanya baru terpenuhi 26 ton, potensi pasar ini sangat membuka potensi budidaya the di kabupaten Banjarnegara.

Beberapa kendala yang dihadapi dalam perkembangan teh di Banjarnegara adalah terbatasnya investasi untuk mendukung pengembangan usaha agrobisnis. Salah satunya terbatasnya data tentang informasi daerah potensial untuk pengembangan perkebunan the. 
Informasi mengenai komoditas unggulan daerah yang mempunyai peluang untuk dikembangkan ini dapat menarik daya tarik para investor karena hasil evaluasi lahan ini dapat dipergunakan untuk acuan pertimbangan. Oleh karena itu diperlukan suatu analisa potensi kesesuaian lahan the di Kab. Banjarnegara yang sajikan dalam bentuk informasi geospasial. Salah satu metode penelitian yang dapat digunakan adalah dengan memadukan teknologi penginderaan jauh dan sistem informasi geografis untuk pemetaan kesesuaian lahan teh di Kab. Banjarnegara.

\section{PEMAHAMAN UMUM KESESUAIAN LAHAN}

Kesesuian lahan adalah kecocokan (fitness) suatu jenis lahan untuk penggunaan tertentu. Kecocokan tersebut dinilai berdasarkan analisis kualitas lahan sehubungan dengan persyaratan suatu jenis penggunaan tertentu, sehingga kualitas yang baik akan meberikan nilai lahan atau kelas yang tinggi terhadap jenis penggunaan tertentu. Penilaian yang dilakukan dapat mengacu pada kondisi sekarang atau didasarkan pada kondisi setelah dilakukan perbaikan terhadap kualitas lahan. Yang pertama disebut sebagai kesesuaian sekarang atau kesesuaian aktual (actual suitability), sementara yang kedua adalah kesesuaian potensial (potential suitability) (Baja, 2012).

Struktur klasifikasi kesesuaian lahan terdiri dari empat karegori utama yaitu ordo, kelas, sub kelas dan satuan kesesuaian lahan. Dalam kategori ordo, satuan lahan hanya dinyatakan sebagai sesuai (S) dan tidak sesuai (N). Satuan lahan yang diiklasifikasikan sebagai ordo $S$ adalah lahan-lahan yang dalam pengusahaannya untuk penggunaan tertentu, baik atau dengan tanpa input, dapat berproduksi dengan baik sehingga menguntungkan tanpa harus menimbulkan resiko kerusakan sumber daya lahan. Pada ordo N, lahan memiliki satu atau beberapa kualitas yang membatasi pengusahaan jenis penggunaan lahan tertentu pada taraf dimana pengaruh pembatas tersebut menghalangi penggunaan secara lestari jenis penggunaan tersebut (Baja, 2012).

Kategori $\mathrm{S}$ dan $\mathrm{N}$ dibagi masing-masing ke dalam kelas S1, S2 dan S3, N1 dan N2. Menurut Baja
(2012) diskripsi masing-masing kelas sebagai berikut :

- Kelas S1 (sangat sesuai) : lahan-lahan dengan tanpa pembatas atau hanya memiliki pembatas yang sangat ringan, dan pembatas tersebut tidak berpengaruh terhadap produktivitas atau keuntungan yang diperoleh, serta tidak memerlukan input diatas level ratarata.

- Kelas S2 (sesuai) : lahan-lahan dengan beberapa pembatas yang mempengaruhi produktivitas, dan pembatas tersebut agak berat sehingga mempengaruhi pengusahaan suatu jenis penggunaan lahan tertentu secara lestari; pembatas-pembatas yang ada dapat menurunkan produksi atau keuntungan dan meningkatnya kebutuhan akan input untuk perolehan keuntungan dari penggunaan tertentu.

- Kelas S3 (sesuai marjinal) : lahan-lahan dengan beberapa pembatas yang mempengaruhi produktivitas, dan pembatas tersebut cukup berat untuk tujuan pengusahaan suatu jenis penggunaan lahan tertentu secara lestari; pembatas-pembatas yang ada telah sampai pada taraf yang sangat berpengaruh terhadap penurunan produksi atau keuntungan, dan dibutuhkannya input untuk perolehan keuntungan dari penggunaan tertentu.

- Kelas N (tidak sesuai ) : lahan-lahan dengan pembatas yang cukup berat dan belum bisa diatasi pada masa sekarang maupun yang akan datang; pembatas tersebut cukup berat sehingga mempengaruhi pengusahaan suatu jenis penggunaan lahan tertentu secara lestari.

Subkelas kesesuaian mencerminkan jenis pembatas yang dimiliki oleh suatu satuan lahan tertentu sedangkan setiap satun kesesuaian lahan memiliki jenis atau kumpulan jenis pembatas tertentu yang berbeda dari lainnya dalam hal kebutuhan pengelolaan pada tingkat detail.

\section{METODOLOGI PENELITIAN}

\section{Data Dan Peralatan}

\section{- Data}

Data yang digunakan dalam penelitian ini adalah:

1. Peta RBI 1:25.000

2. Data curah hujan dari stasiun cuaca 
3. Citra Aster

4. Citra Quickbird

5. Citra Landsat 8 Band Thermal
1) Data peta kelerengan dan ketinggian diperoleh

2) dari pengolahan citra aster GDEM dan kontur peta RBI 1:25.000

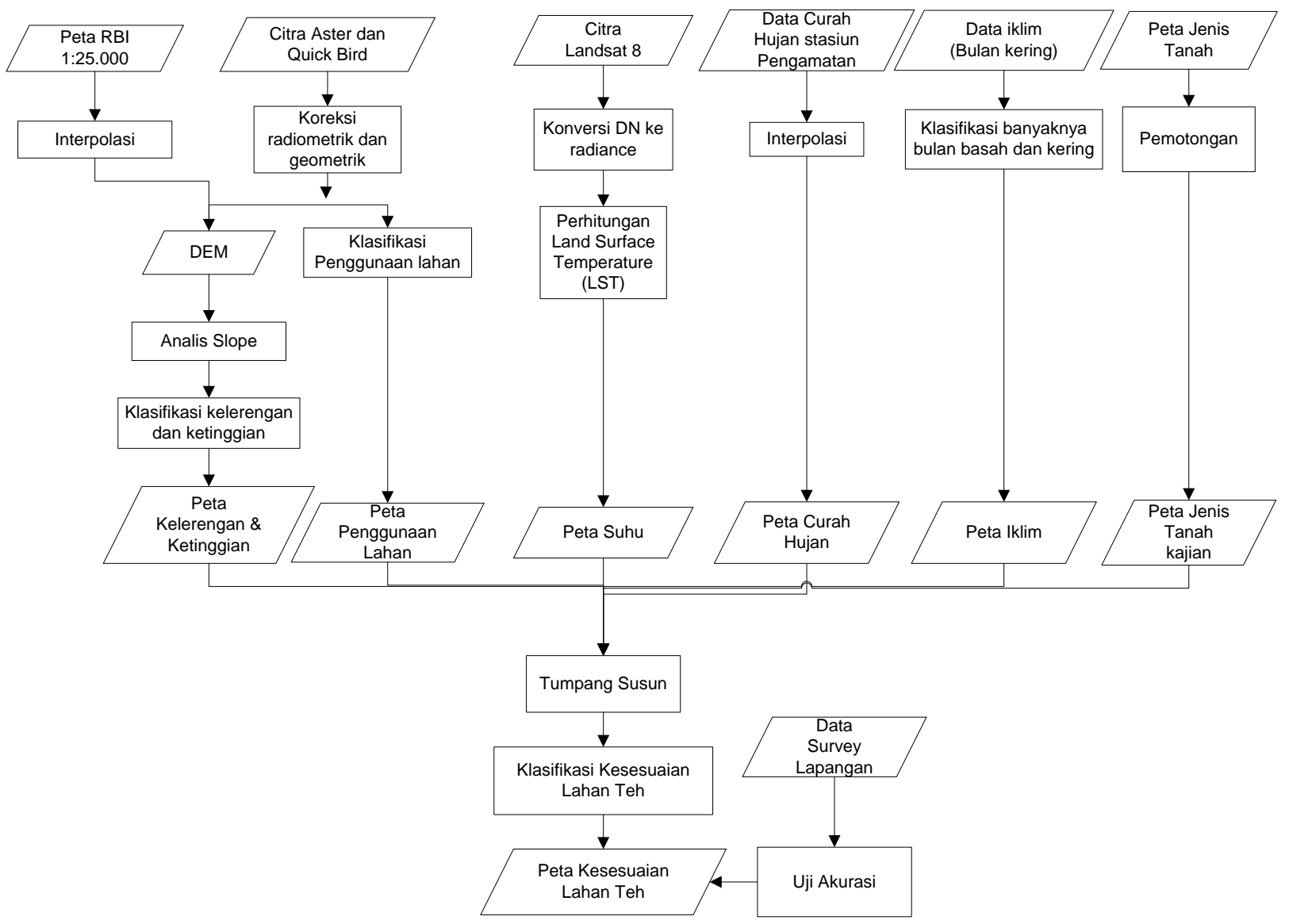

Gambar 1. Diagram Alir Penelitian

6. Peta Jenis Tanah

7. Data Iklim

\section{- Peralatan}

Peralatan yang digunakan dalam penelitian ini adalah:

1. Software pengolah Citra

2. Software SIG

\section{Metode Penelitian}

Penelitian ini dilaksanakan di lima Kecamatan bagian utara Kab. Banjarnegara. Lima kecamatan ini dipilih dikarenakan kondisi iklim dan topografi di lima kecamatan ini yang paling memungkinkan untuk pengembangan tanaman teh. Tahapantahapan analisis dapat dilihat pada Gambar 1.

Uraian pelaksanaan diagram alir adalah sebagai berikut :
3) Peta penggunaan lahan diperoleh melalui klasifikasi land use dengan data citra satelit resolusi tinggi quickbird tahun 2012 menggunakan metode supervised clasification

4) Pengolahan peta suhu diperoleh menggunakan band thermal citra Landsat 8 menggunakan algoritma brightness themperature Yale. Data citra landsat 8 yang digunakan dari Agustus 2013-November 2014 yang kemudian dilakukan proses perataan dari pengolahan data tersebut.

5) Proses interpolasi data curah hujan dari data curah hujan setiap stasiun cuaca dilakukan menggunakan metode interpolasi kriging untuk menyusun peta curah hujan tahunan.

6) Untuk peta jenis tanah dilakukan proses pemotongan wilayah kajian sehingga diperoleh peta jenis tanah wilayah studi. 
7) Hasil parameter peta ketinggian, kelerengan, suhu, curah hujan, penggunaan lahan, iklim dan curah hujan dilakukan tumpang susun (overlay) untuk mendapatkan peta kesesuaian lahan.

8) Selanjutnya dilakukan klasifikasi kesesuaian lahan berdasarkan metode yang ditetapkan oleh FAO (Food and Agriculture Organosation). Adapun dasar kesesesuain lahan the dapat dilihat pada Tabel 1.

Tabel 1. Kriteria kesesuaian lahan teh

\begin{tabular}{|c|c|c|c|c|c|}
\hline \multirow[b]{2}{*}{ No. } & \multirow{2}{*}{$\begin{array}{c}\text { Persyaratan } \\
\text { penggunaan / } \\
\text { karakteristik } \\
\text { lahan }\end{array}$} & \multicolumn{4}{|c|}{ Kelas kesesuaian lahan } \\
\hline & & S1 & S2 & S3 & $\mathbf{N}$ \\
\hline 1 & Temperatur & & $21-24$ & $24-27$ & $>27$ \\
\hline 1. & (oC) & $19-21$ & $17-19$ & $14-17$ & $<14$ \\
\hline 2. & $\begin{array}{l}\text { Ketinggian } \\
\text { tempat dpl } \\
\text { (m) }\end{array}$ & $\begin{array}{l}900- \\
1200\end{array}$ & $\begin{array}{l}1200- \\
1500 \\
400- \\
900\end{array}$ & $\begin{array}{l}1500- \\
2000 \\
0-400\end{array}$ & $\begin{array}{c}>120 \\
0\end{array}$ \\
\hline 3. & $\begin{array}{l}\text { Curah hujan } \\
(\mathrm{mm}) \text { tahunan }\end{array}$ & $\begin{array}{l}2500- \\
4000\end{array}$ & $\begin{array}{l}1800- \\
2500 \\
4000- \\
5000\end{array}$ & $\begin{array}{c}1300- \\
1800 \\
5000- \\
6000\end{array}$ & $\begin{array}{c}<130 \\
0 \\
>600 \\
0\end{array}$ \\
\hline 4. & $\begin{array}{l}\text { Lamanya } \\
\text { bulan kering } \\
\text { (bln) }\end{array}$ & $0-2$ & $2-3$ & $3-4$ & $>4$ \\
\hline 5. & $\begin{array}{c}\text { Kelerengan } \\
(\%)\end{array}$ & $<8$ & $8-16$ & 16-30; & $>30$ \\
\hline
\end{tabular}

Sumber: Balai Penelitian Tanah, Pusat Penelitian dan Pengembangan Tanah dan Agroklimat RI, 2003

\section{HASIL DAN PEMBAHASAN}

\section{Kelerengan}

Berdasarkan kelerengannya, Wilayah Pekerjaan berada pada lereng antara $(<8 \%)$ sampai dengan lebih dari $40 \%$. Wilayah yang berada pada lereng dibawah 8\% seluas 1021,45 Ha meliputi Kecamatan Kalibening dan Batur. Selanjutnya untuk kelerengan antara 8\% - 15\% meliputi wilayah Kec. Batur, Kalibening, Pagentan, Pejawaran, dan Kecamatan Wanayasa dengan luas total 3995,23 Ha. Kemudian wilayah dengan kelerengan 16\% - 25\% tersebar di Kec. Batur, Kalibenig, Pagentan, Pejawaran, dan Kec. Wanayasa dengan luas total $6128 \mathrm{Ha}$. Untuk wilayah dengan kelerengan 26\%-40\% merupakan wilayah yang cukup dominan kelerenganya di wilayah pekerjaan yaitu dengan luas $11309,58 \mathrm{Ha}$. Sedangkan wilayah dengan kelerengan lebih dari $40 \%$ seluas 12035,73 Ha merupakan wilayah yang memiliki tingkat kelerengan yang paing dominan di wilayah pekerjaan. Untuk lebih jelasnya dapat dilihat peta kelerengan pada Gambar 2.

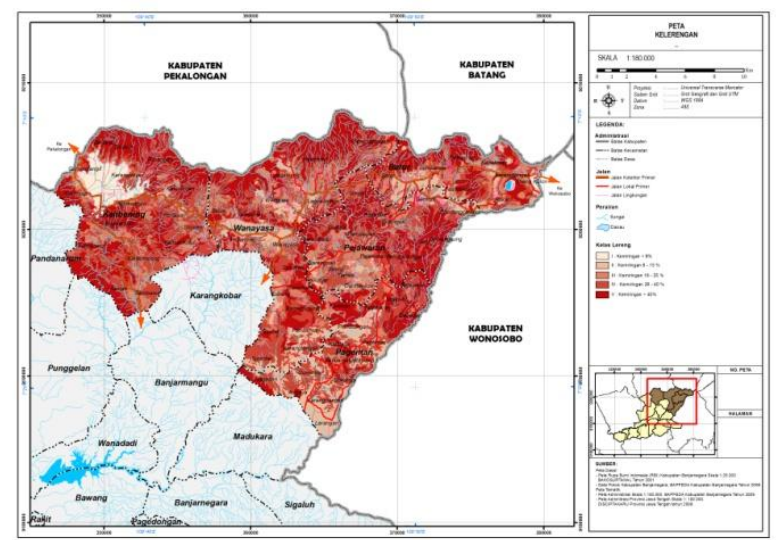

Gambar 2. Peta Kelerengan

\section{Curah Hujan}

Peta curah hujan didapatkan dari hasil interpolasi data 13 stasiun hujan di sekitar wilayah pekerjaan. Hasil interpolasi menunjukkan bahwa curah hujan rata-rata per tahun di Wilayah Pekerjaan berkisar antara 2500 sampai dengan $3500 \mathrm{~mm} /$ th. Untuk lebih jelasnya dapat dilihat pda Gambar 3. Peta Curah Hujan.

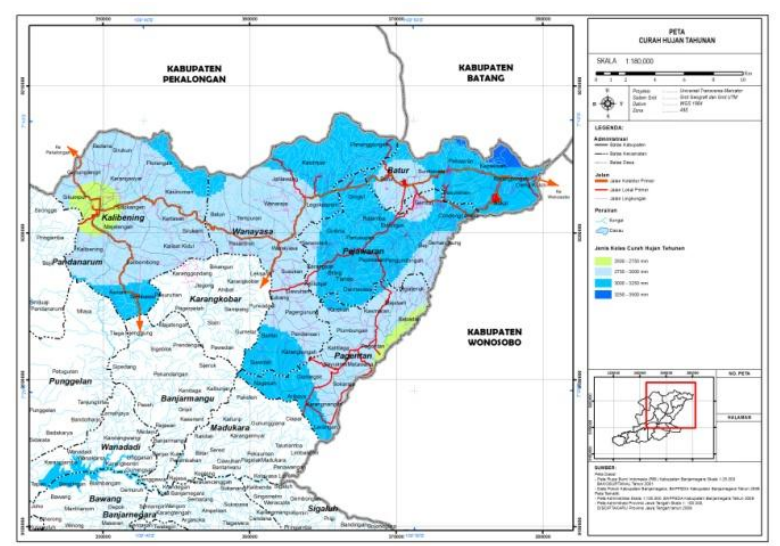

Gambar 3. Peta curah hujan

Suhu

Kondisi klimatologi di wilayah Kabupaten Banjarnegara khususnya lima kecamatan yang berada di bagian utara Banjarnegara seperti halnya kebanyakan wilayah di Indonesia yang beriklim tropis, dengan bulan basah umumnya lebih banyak daripada bulan kering. Pada umumnya bulan basah terjadi antara bulan September-Maret. Sedangkan bulan kering berkisar antara April-Agustus. Puncak musim hujan berada pada bulan Desember-Januari. 
Peta temperatur/suhu didapatkan dari pengolahan Citra Landsat menggunakan Band Thermal (Band 10 dan 11) Agustus 2013November 2014 dengan menggunakan algoritma Yale University. Berdasarkan hasil pengolahan tersebut didapatkan bahwa pada wilayah pekerjaan memiliki suhu berkisar antara $13-32{ }^{\circ} \mathrm{C}$. Untuk lebih jelasnya dapat peta suhu/temperatur pada Gambar 4.

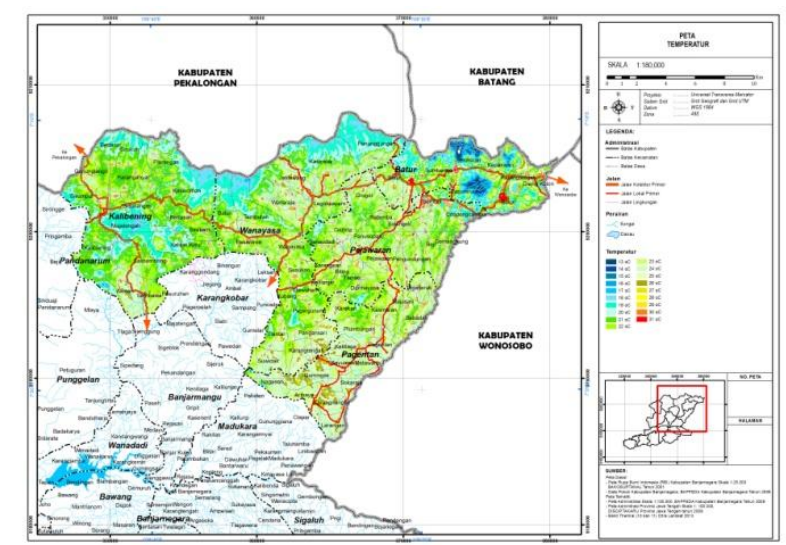

Gambar 4. Peta suhu/temperatur

\section{Jenis Tanah}

Jenis tanah pada Wilayah Pekerjaan terdiri dari tanah aluvial, landosol, grumosol, atosol dan podsolik merah kuning. Berikut penjelasan untuk masing-masing jenis tanah:

a. Tanah aluvial : dengan asosiasinya, berwarna kelabu coklat dan hitam, sifatnya beraneka ragam. Produktivitas tanah rendah hingga tinggi sesuai untuk pertanian. terdapat pada Kecamatan Batur, Kalibening.

b. Tanah andosol : dengan asosiasi berwarna coklat, coklat kekuning-kuningan, bersifat netral sampai asam. Produktivitas tanah sedang hingga tinggi, cocok untuk tegalan, kebun campuran dan hutan. Terdapat di Kecamatan Wanayasa, Pejawaran, Pagentan, dan Batur.

c. Tanah grumosol : asosiasinya dengan tanah mediteran, sifatnya agak netral, warna kelabu hingga hitam, merah kekuning-kuningan, merah hingga coklat. Produktivitasnya rendah sampai sedang, cocok dipergunakan untuk usaha-usaha persawahan dan tegalan. terdapat di Kecamatan Kalibening, Pagentan, Wanayasa. d. Tanah latosol : berarsosiasi dengan andosol, sifatnya agak asam hingga netral, warnanya beraneka ragam yaitu kelabu, coklat, hitam coklat kemerah-merahan. Tingkat kesuburan tanah sedang sampai tinggi. Sesuai untuk usaha pertanian, kebun campuran, pertanian sayur-sayuran dan hutan. Terdapat pada Kecamatan Wanayasa, Pejawaran, Kalibening dan Pegentan.

e. Tanah podsolik merah kuning : tanah bertekstur liat, struktur blok di lapisan bawah, konsistensi teguh, bersifat asam dengan $\mathrm{pH}$ kurang dari 5,5. Terbentuk pada daerah dengan curah hujan antara 2500 sampai 3000 $\mathrm{mm}$ tiap tahun serta biasanya berada pada ketinggian di atas 25 meter di atas permukaan laut. Terdapat di sekitar tegalan pada Kecamatan Kalibening.

Untuk lebih jelasnya dapat dilihat pada Gambar 5. Peta Jenis Tanah.

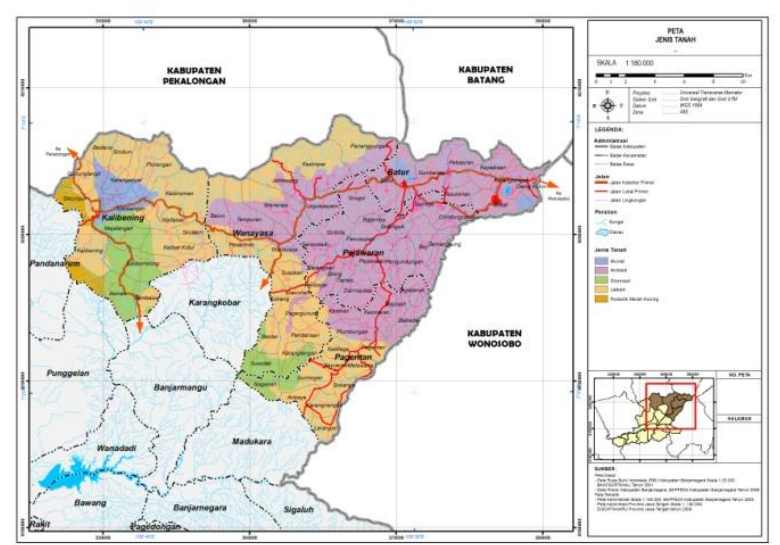

Gambar 5. Peta Jenis Tanah

\section{Penggunaan Lahan}

Berdasarkan hasil interpretasi citra Quickbird tahun 2012 yang telah direktifikasi dan pengecekan medan (groundcheck), penggunaan lahan pada 5 kecamatan yang termasuk wilayah pekerjaan (Kecamatan Batur, Pejawaran, Pagentan, Wanayasa, dan Kalibening) terdiri dari penggunaan lahan air tawar, belukar/semak, gedung, hutan, hutan produksi terbatas, hutan produks tetap, kebun, permukiman, sawah irigasi, sawah tadah hujan dan tegalan.

Penggunaan lahan terbesar di wilayah pekerjaan adalah penggunaan lahan tegalan seluas $17.374,33 \mathrm{Ha}(50,63 \%)$ dan hutan produksi 
terbatas seluas $6.394,80$ ha $(18,64 \%)$. Untuk lebih jelasnya penggunaan lahan di wilayah lima kecamatan tersebut dapat dilihat pada peta penggunaan lahan Gambar 6 .

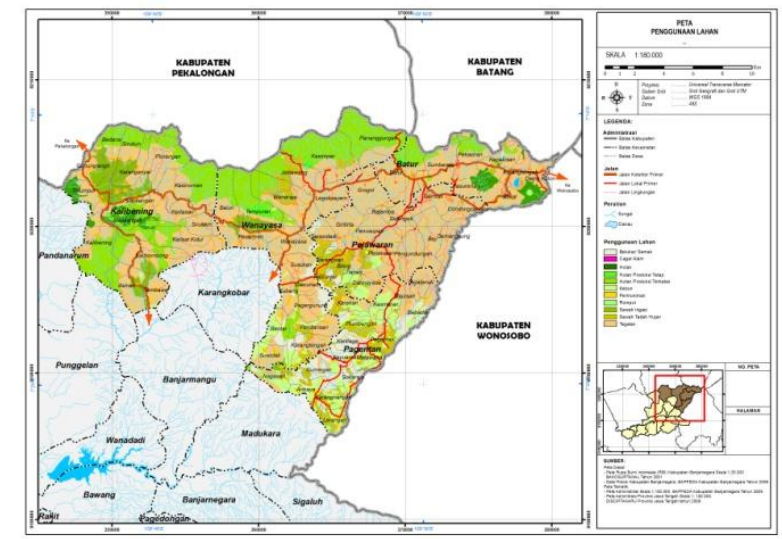

Gambar 6. Peta Penggunaan Lahan

\section{Kesesuaian Lahan Lahan Teh}

Berdasarkan daftar prioritas pengembangan komoditas perkebunan di Kabupaten Banjarnegara, teh merupakan salah satu komoditas unggulan di wilayah studi. Pada wilayah studi tidak ada lahan yang masuk ke dalam kelas sangat sesuai (S1).

Adapun lahan yang sesuai (S2) untuk komoditas teh seluas $2147,21 \mathrm{Ha}(6,58 \%)$ meliputi semua kecamatan di wilayah studi. Lahan yang sesuai (S2) di Kecamatan Batur meliputi Desa Bakal, Batur, Dieng Kulon, Karangtengah, Kepakisan, Pasurenan, Pekasiran, dan Sumberejo. Di Kecamatan Kalibening, lahan yang sesuai (S2) meliputi Desa Bedana, Gununglangit, Kalibening,
Karanganyar, kasinoman, Kertasari, Majatengah, Plorengan, Sidokangen, Sikumpul dan Sirukun. Lahan yang sesuai (S2) di Kecamatan Pagentan tersebar di desa Aribaya, Babadan, Gumingsir, Kalitlaga, Karangnangka, Kasmaran, Kayuares, Larangan, Metawana, Nagasari, Pagentan, Plumbungan dan Sokaraja. Adapun di Kecamatan Kecamatan Pejawaran, lahan yang sesuai (S2) meliputi Desa Biting, Condongcampur, Darmayasa, Gembol, Kalilunjar, Karangsari, Pejawaran, Sarwodadi dan Tlahab. Sementara lahan yang sesuai untuk teh di Kecamatan Wanayasa adalah Desa Balun, Bantar, Jatilawang, Karangtengah, Kasimpar, Kubang, Legoksayem, Pananggungan, Pandansari, Pesantren, Suwidak, Tempuran, Wanaraja, dan Wanayasa.

Selanjutnya, lahan yang sesuai marjinal (S3) untuk tanaman teh seluas $6882,32 \mathrm{Ha}(21,10 \%)$ tersebar di seluruh Desa di Kecamatan Pagentan, Wanayasa, Kalibening, Pejawaran dan Batur kecuali Desa Semangkung, Kecamatan Pejawaran. Sisanya adalah lahan yang tidak sesuai (N) untuk tanaman teh seluas $23584,58 \mathrm{Ha}(72,31 \%)$. Untuk lebih jelasnya dapat dilihat pada Gambar 6 .

Validasi dilakukan dengan pengecekan lapangan terhadap 32 titik potensi pengembangan teh. Hasilnya menunjukkan tingkat kebenaran hasil klasifikasi kesesuaian mencapai $88 \%$. 
Tabel 4. Kesesuaian lahan the setiap kecamatan

\begin{tabular}{|c|c|c|c|c|c|c|}
\hline \multirow{2}{*}{ No } & \multirow{2}{*}{ Kecamatan } & \multicolumn{4}{|c|}{ Luas Kelas Kesesuaian Lahan (Ha) } & \multirow{2}{*}{ Jumlah } \\
\hline & & S1 & S2 & S3 & $\mathbf{N}$ & \\
\hline 1 & Pagentan & 0,00 & 240,48 & 1405,98 & 3189,97 & $4.836,43$ \\
\hline 2 & Wanayasa & 0,00 & 545,50 & 1899,64 & 6743,63 & $9.188,77$ \\
\hline 3 & Kalibening & 0,00 & 815,05 & 1435,66 & 6577,75 & $8.828,46$ \\
\hline 4 & Pejawaran & 0,00 & 249,20 & 1340,84 & 4265,44 & $5.855,47$ \\
\hline \multirow[t]{3}{*}{5} & Batur & 0,00 & 296,99 & 800,20 & 2807,80 & $3.904,99$ \\
\hline & Jumlah & 0,00 & 2147,21 & 6882,32 & 23584,58 & $32.614,12$ \\
\hline & $\%$ & 0,00 & 6,58 & 21,10 & 72,31 & 100,00 \\
\hline
\end{tabular}

Sumber : Hasil Analisis, 2014

Keterangan :

S1: Sangat Sesuai , S2 : Sesuai, S3 : Sesuai Marjinal dan N : Tidak Sesuai

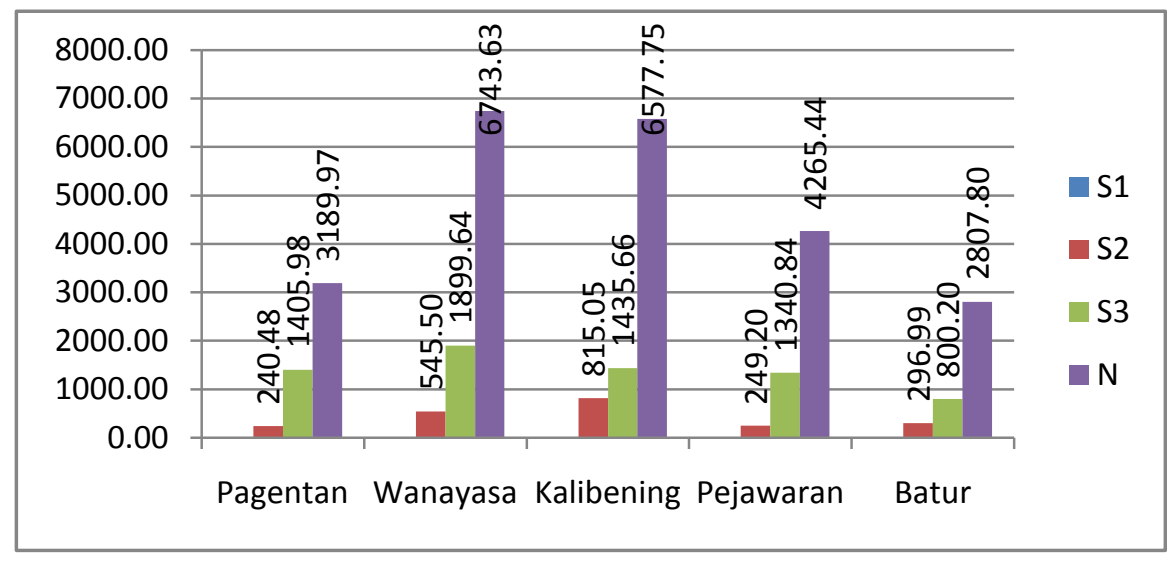

Gambar 7. Grafik kesesuaian lahan teh setiap kecamatan

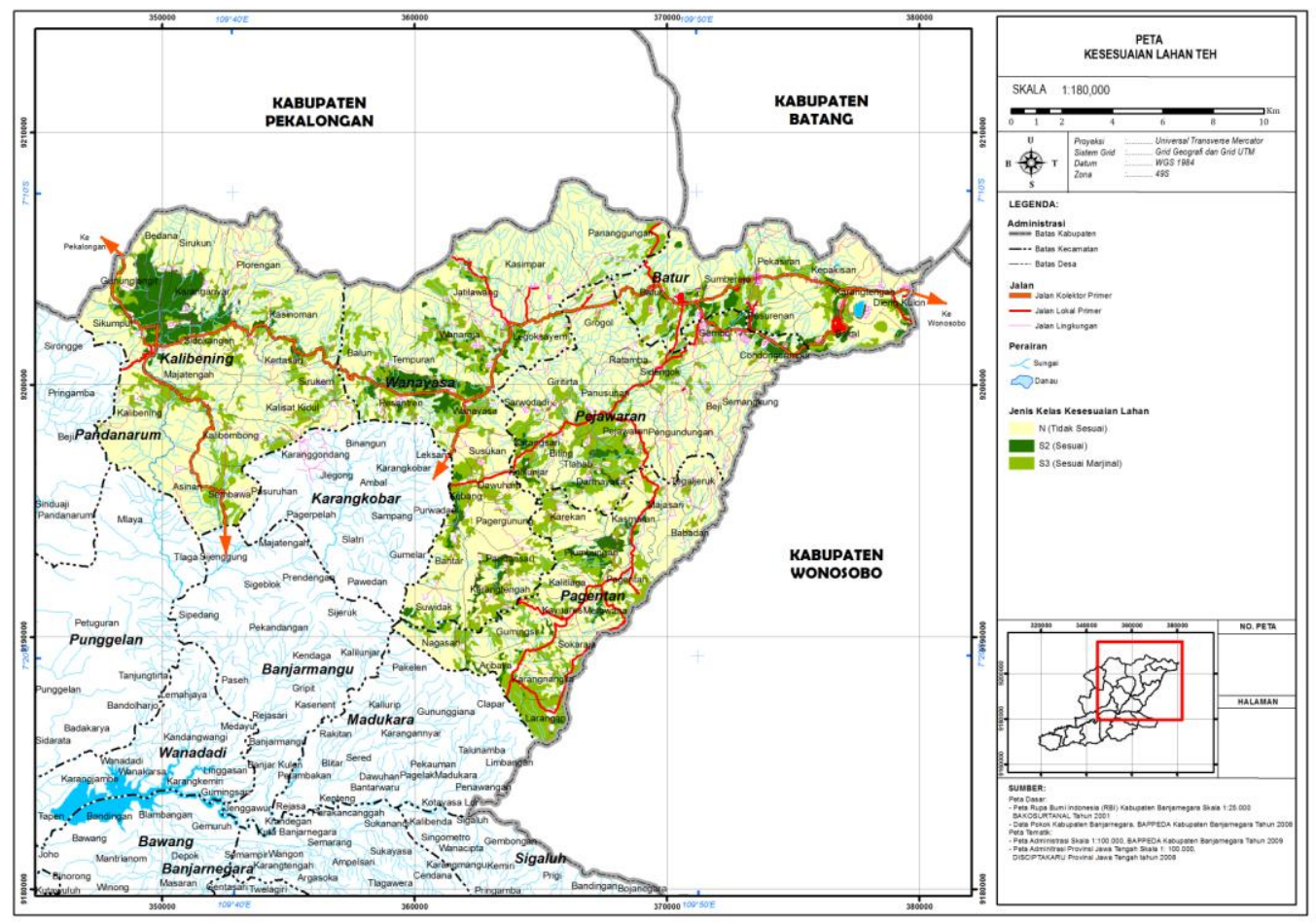

Gambar 8. Peta kesesuaian lahan teh 


\section{PENUTUP}

\section{Kesimpulan}

Adapun kesimpulan yang dapat diambil dari penelitian ini adalah sebagai berikut :

1. Area kesesuaian lahan teh di wilayah kabupaten Banjarnegara bagian utara mencapai 2147,21 $\mathrm{Ha}$ (6,58\%) untuk kategori Sesuai (S2), seluas 6882,32 Ha (21,10\%)untuk kategori sesuai marjinal (S3) dan selebihnya seluas $23584,58 \mathrm{Ha}(72,31 \%)$ tidak sesuai untuk budidaya teh.

2. Kesesuaian lahan teh tersebar merata pada lima kecamatan Kalibening, Wanayasa, Pagentan, Pejawaran dan Batur.

\section{Saran}

Untuk analisa selanjutnya pada variabel kelerengan perlu diteliti kembali terkait arah lereng. Hal ini terkait pada lama penyinaran matahari daerah dataran tinggi berbeda dengan dataran rendah.

\section{DAFTAR PUSTAKA}

Baja, S. 2012.Perencanaan Tata Guna Lahan dalam Pengembangan Wilayah.Penerbit ANDI, Yogyakarta.

Dewan Teh Indonesia. "Konsumsi Teh Dunia". 2015. http://www.indoteaboard.org ( 30 Jan. 2015).

Djaenudin, D., Marwan H., Subagyo H., dan A. Hidayat. 2003. Petunjuk Teknis untuk Komoditas Pertanian. Edisi Pertama tahun 2003, ISBN 979-9474-25-6. Balai Penelitian Tanah, Pusat Penelitian dan Pengembangan Tanah dan Agroklimat, Bogor,Indonesia 